Bayero Journal of Pure and Applied Sciences, 4(2): 69 - 79

Received: December, 2010

Accepted: August, 2011

ISSN $2006-6996$

\title{
NITRATE-INDUCED OXIDATIVE STRESS AND THE EFFECTS OF DIETARY ANTIOXIDANT VITAMINS C, E AND A: INSIGHTS FROM EXPERIMENTAL AND CLINICAL STUDIES
}

\author{
Yarube, I.U. \\ ${ }^{1}$ Department of Human Physiology, Faculty of Medicine, Bayero University, Kano. \\ dryarube@yahoo.com
}

\begin{abstract}
Various studies on nitrates and nitrites including their widespread applications, mechanisms of action and biological effects due to their ability to induce oxidative stress have been reviewed. The current vigorous research efforts to explore the potential uses of antioxidants in various disease conditions have been critically examined and presented. The review is also focused on Vitamins $C, E$ and $A$, among other antioxidants, as they can be chiefly obtained in natural form from fruits and vegetables in almost all parts of the world.
\end{abstract}

Keywords: nitrates, oxidative stress, dietary antioxidants, vitamin C, vitamin E, vitamin A

\section{INTRODUCTION}

Nitrates are toxic inorganic chemicals commonly found in the environment, foods, and in the bodies of living humans and animals (Antipina et al., 1990; Oladele et al., 1997; IPCS, 1999). Individuals at risk of exposure to nitrates include workers in industries, where fertilizers and explosives are manufactured. They may be chronically exposed to low doses of nitrates through inhalation of dusts containing nitrate salts. The dusts can also dissolve in sweat and expose the skin to concentrated solutions of the salts (IPCS, 1999). This also applies to the farmers who work with fertilizers without using protective gloves, though they are only periodically exposed. Infants can be exposed to nitrates in water used to dilute infant formula (Donovan, 1990; ATSDR, 2001), and while taking mashed carrot used to treat infant diarrhoea, are at special risk of acute poisoning due to immaturity of their enzyme system for regeneration of haemoglobin (IPCS, 1999). Acute poisoning has been reported to occur in animals after feeding with large quantity of food and water contaminated with nitrates and nitrites. The widespread use of nitrate salts in agriculture, food and pharmaceutical industries (Awodi et al., 2005; Manassaram et al., 2006), coupled with high rates of air-borne nitrogen compounds emission from industries and automobiles ((USGS, 1996) make the chances of exposure to these chemicals even more inevitable.

Toxicities by nitrates have been well documented. However, with the current widespread use of organic fertilizers on impoverished agricultural lands (Oladele et al., 1997), coupled with increasing water scarcity necessitating the use of water from unregulated sources, the impact of nitrate toxicity is likely to be worse than ever and therefore necessitating further research in this area. Several on-going studies are focused on the modulatory role of many antioxidants during oxidative stress induced by nitrates and other substances.

\section{Sources of exposure to nitrates}

The major source of nitrate in the human body is through intake of food and water (IPCS, 1999). Vegetables may account for more than $70 \%$ of the nitrates (ATSDR, 2001), while up to $21 \%$ of total intakes of nitrates in a typical human diet is from drinking water (Wogan et al., 1995; ATSDR, 2001; Manassaram et al., 2006). Drinking water may contain variable amounts of nitrates and the statutory limits vary from country to country, with maximum being $44.3 \mathrm{mg} \mathrm{NO}_{3} / \mathrm{L}$ and $50 \mathrm{mg} \mathrm{NO}_{3} / \mathrm{L}$ in the United States of America and European Union, respectively (IPCS, 1999). Other sources of exposure to nitrates include textile, cement and nuclear industry, odour and corrosion control, coagulation of latexes and photography (ATSDR, 2001). Sodium nitrite is used as an antidote in cyanide (IPCS, 1999) and hydrogen sulphide poisoning (Khmelnitsky, 1990). Exposure can also occur through intake of nitrosable drugs (Brenda et al., 2004), and as psychedelics or in suicidal attempts (ATSDR, 2001). There is also endogenous nitrate and nitrite formation through nitric oxide (NO) (Oladele et al., 1997). Thus, the widespread usage of nitrates in the industries, agriculture and medicine has significantly increased the risk of exposure of man to the toxic effects of these compounds.

\section{Pathophysiology of Nitrate Toxic Effects Biotransformation of nitrates in the body} The principal concern with exposure to nitrates is their biological reduction to reactive and toxic nitrites (Manassaram, 2006). Nitrates themselves are rather harmless. In humans, ingested nitrate is rapidly absorbed from the proximal small intestine into the circulation. Nitrate then reaches the large bowel from the blood, where it is rapidly converted to highly reactive and toxic nitrite. High $\mathrm{pH}$ and presence of appropriate intestinal microbial flora favour this conversion reaction (ATSDR, 2001). 
The formed nitrite is reabsorbed into the blood, where it reacts with the ferrous $\left(\mathrm{Fe}^{2+}\right)$ iron of deoxyhaemoglobin to form methaemoglobin, with iron in the ferric $\left(\mathrm{Fe}^{3+}\right)$ state.

Nitrates are rapidly converted in the liver to denitrated metabolites and inorganic nitrites, which are then excreted in the urine. Approximately $60-70 \%$ of ingested nitrate dose is excreted in the urine within the first 24 hours (IPCS, 1999). Half-lives of parent nitrate compounds are usually $<1 \mathrm{hr}$, while that of metabolites ranges from 1-8 $\mathrm{hr}$.

\section{Reactions with Haemoglobin}

The major mechanism of acute effects of nitrates and nitrites is methaemoglobinaemia (IPCS, 1999; ATSDR, 2001). Methaemoglobin reduces the oxygen-carrying capacity of the blood and shifts the oxyhaemoglobin dissociation curve to the left, thus interfering with the unloading of oxygen (Dudarev, 1987; Donovan, 1990; IPCS, 1999). Erythrocyte reductases - NADH-dependent and NADPH-dependent, reduce methaemoglobin back to haemoglobin (Prugar and Prugavova, 1990; ATSDR, 2001). A physiological methaemoglobinaemia (1-2\% of total haemoglobin) is typical in humans as a result of exposure to oxidising substances and diet (ATSDR, 2001). A congenital methaemoglobinaemia (blue baby syndrome) can be found in persons with either haemoglobin $\mathrm{M}$ disease or deficiency of $\mathrm{NADH}$-dependent methaemoglobin reductase. Persons with an $\mathrm{NADH}-$ dependant reductase deficiency might be more susceptible to developing acquired symptomatic methaemoglobinaemia after exposure to nitrates and nitrites (ATSDR, 2001). Methaemoglobanaemia may occur concurrently with sulfhaemoglobinaemia, which is usually benign but may confound the diagnosis (ATSDR, 2001).

Nitrites also can oxidise haemoglobin, causing denaturation (Heinz bodies) and erythrocyte haemolysis, resulting in haemolytic anaemia (ATSDR, 2001). Haemolysis is enhanced through the destruction of the phospholipid bilayer of the erythrocyte membrane by reactive NO released by the nitrates (Azhipa et al.,1990; Oladele et al.,1997). However, decreased erythrocyte osmotic fragility was reported in rats chronically treated with sodium nitrate (Yarube, 2008), indicating that the cells have, apparently, developed capacity for adaptation to the toxic effects (Bensoltane et al., 2006).

\section{Free radicals formation}

Nitrates and nitrites have been reported to induce freeradical generation in vivo (Azhipa et al., 1990; Rubenchik, 1990; Kashko et al., 1993) through the release of nitrite and NO which overwhelm the host antioxidant defence system. Nitric oxide is a potentially reactive free radical gas and a biological messenger in many tissues (Moncada et al., 1991; Hryhorenko et al., 1995; Kerwin, 1995; Peranovich et al., 1995). In low nanomolar concentrations, NO functions as a transmitter in brain and other tissues. Whereas in near-micromolar concentrations, NO which is destroyed partly by cytochrome P450 oxidoreductase (CYPOR) is associated with toxicity and cell death (Hall et al., 2009). Nitrates inhibit electron transport in the mitochondrial respiratory chain, leading to blockade of cytochrome oxidase (Antonov et al., 1989; Babsky and Shostakovskaya, 1992). This results in the formation of molecular oxygen (Oladele et al., 1997).

\section{Formation of $\mathbf{N}$-nitroso compounds}

$\mathrm{N}$-nitroso compounds are produced in the intestine as a result of interaction of nitrite and nitric oxide with biogenic amines formed from amino acids (such as leucine and valine) under the influence of decarboxylase of Escherichia coli, Salmonella spp. and other pathogenic bacteria (Antipina et al., 1990; Antonov et al., 1989). The teratogenic and embryotoxic effects of nitroso compounds such as $\mathrm{N}$-nitroso dimethylamines, $\mathrm{N}$ - nitroso diethylamine and $\mathrm{N}$-nitroso methyl-n-butylamine, are based on their ability to pass through the placenta (Rubenchik et al., 1983). The interaction of alkylating products with nitrogen bases of the DNA underlies the mechanism of cancer formation by nitroso compounds. This interaction does not occur chaotically, but rather in a specific pattern at the $\mathrm{N}-7$ position of guanidine and rarely at $\mathrm{N}-1, \mathrm{~N}-3$ and $\mathrm{N}-7$ positions adenine, $\mathrm{N}-3$ and $\mathrm{O}^{6}$ positions of guanine, and $\mathrm{O}^{4}$ position of thiamine. The alkylation of bond C-P which is important in the manifestation of the carcinogenic activity of nitroso amines, produced in the body following nitrate and nitrite poisoning, is apparently related to NO formation (Sorokin, 1991).

\section{Other mechanisms of action}

Chronic toxicity of nitrates has been shown to be connected to the formation of carcinogenic N-nitroso compounds (Antipina et al., 1990; Kasyanenko et al., 1992), impairment of acid-base balance, resulting in metabolic acidosis (Sidoryak and Minyaylenko, 1991), stores depletion of vitamins C and E stores (Karpovsky, 1994; Oladele et al., 1997) as well as vitamin A level in the body (Dutsheyko, 1989). Nitrates decrease heat production and cause impairment of energy metabolism in the erythrocyte due to inhibition of redox reaction in the respiratory chain (Dudarev, 1987; Zadorozhnaya, 1991). Nitrates, especially in high concentrations, may impair the activity of digestive enzymes and thyroid gland as well as vitamin A metabolism (Oladele et al., 1997). This may result in cardiac dysfunction and central nervous system lesions. Nitrates may have cumulative effects in humans (ATSDR, 2001). At the same time, evidence of tolerance and adaptation to nitrate toxicity has been reported (Bensoltane et al., 2006).

\section{Nitrates as Health Hazards to Humans and Animals \\ Acute and chronic toxicity of nitrates}

Toxic effects of nitrates vary with age, physiological status, diet and other factors (Lewicki et al., 1994). While acute poisoning usually occurs following intake of large doses of nitrates and nitrites, chronic poisoning occurs as a result of intake of small toxic doses over long periods. Toxicity of nitrate is due primarily to its in vivo conversion to nitrite after ingestion (NAS, 1977; ATSDR, 2001).

\section{Haematologic effects}

Shehata (2005) reported significant decrease in haemoglobin concentration, erythrocyte count, total protein, albumin and globulin concentrations in rabbits exposed to nitrates in drinking water over a short period. However, repeated ingestions of nitrites into the body have been shown to induce a rise in erythrocyte counts, haemoglobin and haematocrit levels (Ogur et al., 2000), which is an important compensatory mechanism aimed at improving oxygen supply to the tissues (Manassram et al., 2006). 
Consequently, body resistance to effects of acute hypoxic hypoxia is increased (Kislyakov and Volzhskaya, 1993).

\section{Circulatory and CNS effects}

Nitrates, through a mechanism involving $\mathrm{NO}$, depress the vasomotor centre and dilate blood vessels, thus resulting in a sharp fall in blood pressure and circulatory collapse (Antonov et al., 1989). NO has also been implicated in neuronal damage associated with stroke (Chabrier et al., 1992) and myocardial infarction (Vanin et al.,1993). The NO generated in the body during nitrate and nitrite poisoning is involved in regulation of coronary blood vessels (Solodkov et al.,1993). Ammonium accumulation in the body associated with nitrate and nitrite poisoning results in excitation and paralysis of the CNS (Ibragimov, 1991).

\section{Carcinogenicity of Nitrates}

$\mathrm{N}$-nitroso compounds produced from nitrates in vivo have been known to cause malignant tumour in the gastrointestinal tract, brain, liver, lungs and kidneys (Ariens et al.,1976; Gnatyshak, 1988). Zandjani et al. (1994) found slightly increased incidence of stomach cancer in one group of workers with occupational exposure to nitrate fertilizer. Further epidemiological studies among high risk groups, such as fertilizer factory workers, populations leaving around irrigation sites, associated with high intake of vegetables and ground water with high nitrate content, patients on long-term treatment with nitrosable drugs, may provide further evidence in this regard.

\section{Reproductive Toxicity}

In animal studies, Bruning-Fan and Kaneene (1993) indicated that nitrate, nitrite and $\mathrm{N}$-nitroso compounds may traverse the placenta and affect the foetus in utero. L'hirondel and L'hirondel (2000) suggested that the foetoplacental barrier is effective against maternal methaemoglobin from the fourth month of pregnancy in humans. Nitrates and nitrites may induce abortion in experimental animals (Fan and Steinberg, 1996) and decrease in number of litters and live births (Laven et al., 2002). Chronic nitrate exposure depresses progesterone levels in cows, which may be responsible for early reproductive toxicity (Manassaram et al., 2006).

In human studies, an increased risk associated with intake of drinking water with nitrate level above the $\mathrm{MCL}$ by preconception or first trimester pregnant women and neural tube defects, anencephaly (Croen et al., 2001; Brenda et al., 2004); cardiac defects (Cedergren, et al., 2002), and other congenital malformations (Bove et al., 1992) have been reported. Brenda et al. (2004) found an association between neural tube defect affected pregnancy and nitrate level $\geq 3.5 \mathrm{mg} / \mathrm{L}$ nitrate- $\mathrm{N}$. The risk increased drastically for women who took nitrosable drugs simultaneously.

In a study by Tabacova et al. (1997), complications of pregnancy such as anaemia, threatened spontaneous abortion/premature labour and toxaemia were found among women with methaemoglobin levels above the normal physiological (2\%) range. Similarly, Bukowski et al. (2001) found a significant relationship between intrauterine growth retardation and higher nitrate levels in the diet. Significant decrease in sperm counts and normal serum testosterone (Yarube et al., 2009a), thyroxine and progesterone levels (Hansen et al., 2009) were found in rats chronically exposed to nitrate.

\section{Pro-oxidants and Antioxidants}

\section{Pro-oxidants}

A pro-oxidant (free radical) is a molecule containing unpaired electron in its outer shell (Ayo and Oladele,
1996; Punchard and Kelly, 1997), thereby making it unstable, highly reactive and potentially dangerous to body biomolecules such as proteins, lipids, carbohydrates and DNA (Chan et al.,2005). Most free radicals exist only for a fraction of a second before participating in a chemical reaction (Lee et al., 2006). In a reductionoxidation (redox) reaction, the reductant donates electron and becomes oxidised, while the oxidant accepts electron and becomes reduced. If a free radical reacts with a non-radical, another free radical is generated:

$$
A^{\bullet}+B \rightarrow C^{\bullet}
$$

This process creates chain reaction that may be thousands of events long till the free radical is deactivated by an antioxidant (Akinwande and Adebule, 2003). An example of such reaction is lipid peroxidation (LPO) of cytomembrane. Free radicals can be generated in vivo during physiological or pathological processes (endogenous free radicals) (Ayo and Oladele, 1996; Kharitonov and Barnes, 2003; Lee et al., 2006); or introduced into the body, for example, through diet (exogenous free radicals) (Halliwell, et al., 1992; Aruoma, 1994).

Endogenous free radicals include oxygen free radicals (OFRs) such as superoxide $\left(\mathrm{O}_{2}{ }^{-}\right)$, hydrogen peroxide $\left(\mathrm{H}_{2} \mathrm{O}_{2}{ }^{-}\right)$, hydroxyl $\left(\mathrm{OH}^{-}\right)$, lipid peroxide $\left(\mathrm{LOO}^{-}\right)$, alkoxyl (LO) and peroxyl $\left(\mathrm{LO}_{2}^{-}\right)$, nitrogen centred free radicals, e. g. phenyldiazine $\left(\mathrm{C}_{6} \mathrm{H}_{3} \mathrm{~N}=\mathrm{N}\right)$; carbon-centred free radicals e. g. trichloromethyl $\left(\mathrm{CCl}_{3}^{-}\right)$; sulphur centred free radicals; and molecular hydrogen $\left(\mathrm{H}_{2}\right)$ (Karlson, 1997). A chief source of OFRs is the mitochondrial respiratory chain (Cheesman, 1993; Griendling et al., 1994; Bkaily and d'Orleans-Juste, 1999; Singhal et al., 2001; Johannesson et al., 2003; Valderranma et al., 2006). Exogenous pro-oxidants are environmental factors that increase the production of free radicals in the body, and they include radiation, smoking, aluminum, drugs such as bleomycin, anthracycline, methotrexate, nitrofurantoin (Halliwell et al., 1992); some anaesthetics, certain pesticides, pollutants and hypoxic environment (Yoshikawa, 1993).

\section{Antioxidants}

Antioxidants are molecules that serve in biological systems as electron acceptors without subsequent change in their biological activity. Cellular antioxidant enzymes protect against damage caused by exposure to endogenous and exogenous pro-oxidants (Lee et al., 2006). Antioxidants keep the physiological balance between free radical production and its elimination, which is crucial for the survival and functioning of living cells. Endogenous antioxidants are native to the body and include enzymes, for example catalase, superoxide dismutase (Manja et al., 2002), glutathione system, including glutathione peroxidase, glutathione reductase and glutathione transferase (Thomas et al., 1990; Jacob and Jande, 1992; Tomoko et al., 1996; Hultberg and Hultberg, 2006); and ceruloplasmin (Marklund, 1980; Mathys et al., 1995).

Non-enzymatic endogenous antioxidants include copper (Mathys et al., 1995), bilirubin (Maiorino et al., 1991), manganese, metallothionins (Riter and Robinson, 1996), zinc and selenium (Mydlik et al., 2002). Exogenous (nutritional) antioxidants may be naturally occurring (in plant or animal products) or synthetic, taken as normal diet or in form of medicine. They possess free-radical scavenging properties and/or augment endogenous antioxidant status (Seyfulla and Borisoba, 1990). 
Examples include ascorbic acid (vitamin C), a-tocopherol (vitamin $E$ ), beta-carotene or vitamin $A$, omega-3 and omega- 6 fatty acids (vitamins $F_{1}$ and $F_{2}$, respectively), nicotinic acid, riboflabin (Voskrensky and Bobirev, 1992), aspirin (Halliwell, 1996) and nordihydroguaiaretic acid (Floriano-Sanchez et al., 2006; Meyer et al., 2006).

\section{Oxidative stress}

Oxidative stress is defined as a rupture in the prooxidant-antioxidant balance in favour of the former, leading to characteristic changes in biomolecules of all types, and to tissue damage (Mircescu, 2008).

During homeostasis, every process is controlled by two antagonising forces to keep internal environment of the body constant. Over-production and/or decreased elimination of free radicals will cause disturbance in prooxidant and antioxidant balance, resulting in overproduction of the former (Madesh and Balasubramanian, 1997; Guichard et al., 2006). Oxidative stress occurs if the production of reactive oxygen species (ROS) is abnormally increased or antioxidant concentration decreases (Droge et al., 2006). Free radicals and oxidative stress are involved in the pathogenesis of cardiovascular diseases, artherosclerosis, hypertention, diabetes, cancer and chronic inflammatory diseases (Csovari, et al., 1992; Vaziri et al., 2000; Papov et al., 2003; Galan et al., 2006; Dursun et al., 2008; Sezer et al., 2010), increased susceptibility to infection (Halliwell, 1996), damage and mutation of DNA during human ageing process (Lu et al., 1999; Dykens, 2006). Fundamentally, mechanisms of ageing lead to progressive deficits in functions of cells and organs, which cause diseases that ultimately kill the body such as cancers, cardiovascular and neurodegenerative diseases (Cutler and Mattson, 2006). The pro-inflammatory prostaglandin $\mathrm{F}_{2}$ is produced in vitro and in vivo by free radical-catalysed peroxidation of arachidonic acid (Bazan, 1992; Davis et al., 2006). ROS generated by NADPH oxidases are conventionally thought to be cytotoxic and mutagenic, and then induce oxidative stress response (Guichard et al., 2006).

\section{Free radicals and Pathophysiology of Diseases}

Oxygen free radicals readily combine with other molecules such as enzymes, receptors and ion pumps, causing oxidation and inhibition or inactivation of normal functions (Punchard and Kelly, 1997; Sung et al., 2000). They can also interact with nucleic acid, thereby causing alteration in base sequence and mutation (Punchard and Kelly, 1997). The primary target of free-radical reaction is the unsaturated bond in lipids found in cellular membrane (Taha et al., 2004). The most destructive effect of free radicals is initiation of LPO as this can result in run-way chain reactions, leading to destruction of cell membrane (Punchard and Kelly, 1997). LPO, which is initiated by ROS, is the process of auto-oxidation of polyunsaturated fatty acid in response to toxic substances (Boots et al., 2003). The change in membrane lipid composition alters membrane permeability, impairs functions of proteins and lipid-dependent membrane-bound enzymes, leading to alterations of cell volume and haemolysis (Halliwell et al., 1992). LPO and lipid-derived oxidised products have been implicated in the pathogenesis of a variety of diseases (Morriel et al., 2000). Lipid hydroperoxide (LOOH) reacts with other lipids, proteins and nucleic acids, propagating the transfer of electrons and subsequent destruction of cells (Papov et al., 2003). Auto oxidation of monosaccharides such as glucose produces peroxide, oxaldehydes and hydrogen peroxide (Sinclair et al.,
1990). Hydrogen peroxide induces necrosis and apoptosis of cells (Lee et al., 2006). Free radicals can oxidise sulfhdryl-containing amino acids, resulting in denaturation of proteins and inactivation of enzymes (Manassaram et al., 2006).

Oxidative stress is involved in tissue injury associated with a number of conditions, including rheumatoid arthritis, adult respiratory distress syndrome, immunological disorders, diabetes mellitus, hepatic diseases, psoriasis (Lu et al., 1999) and ischaemiareperfusion injury of the heart (Ayo et al., 1990; Sax et al., 1992). Other conditions associated with changes in free-radical generation include erythrocytopathy in malaria, sickle-cell anaemia, favism, thalasaemia, $\mathrm{G}_{6} \mathrm{PD}$ deficiency (Seyfulla and Borisova, 1990) and trypanosomosis (Igbokwe et al., 1992), lung diseases, such as emphysema, pneumoconiosis, smoking-related lung diseases (Akinwande and Adebule, 2003); infectious diseases such as tuberculosis (Gutkin et al., 1986), influenza (Gorbanov et al., 1992), chlamidial infections (Azenabor et al., 1994); hyperoxygenation syndromes; for example, hyperbaric oxygen and hyperoxygenation respiratory disorders (Del Maestro, 1980; Clark, 1988).

The brain undergoes neurodegeneration, when excess free radicals overwhelm the antioxidative defence system during senescence, head injury or neurotoxic conditions (Chiveh et al., 2000). Free radical-mediated oxidative stress is involved in Alzheimer's disease (Gramov et al., 1993; Opaza et al., 2000), Parkinson's disease (Chiveh et al., 2000) as well as hypoxic and ischaemic brain injuries (Takano et al., 2005). ROS and reactive nitrogen species cause brain damage as a result of high lipid content and low antioxidant defence in the brain (Metodiewa and Koska, 2000). The extent of free radical-induced oxidative stress can be exacerbated by decrease in efficiency of antioxidants in the circulation and is associated with increased risk of cancer (Manja et al., 2002). Oxidative modification of LDL which increases lipid peroxidation and decreases activity of antioxidant systems may contribute to the acceleration of atherosclerosis in renal failure (Mydlik et al., 2002). Oxidative stress is suggested to be central to aging process with reducing endogenous antioxidant defence capacity and repair mechanisms (Halliwell, 1994). The popular use of antioxidant vitamins illustrate the growing awareness of oxidative stress as an important factor in aging process (Droge et al., 2006).

\section{Mechanisms of Disease Prevention by Antioxidants}

It is recognised that a major protective goal of antioxidants is to avoid radical-induced damage to polyunsaturated fatty acids and essential fatty acids, in particular the omega- 3 and omega- 6 fatty acids (Karlson, 1997). Antioxidants can act by scavenging biological ROS, preventing their formation or repairing the damage they induce (Halliwell, 1994). Primary antioxidants prevent the formation of new free radicals species by converting existing free radicals into less harmful molecules before they have chance to induce cellular damage (Karlson, 1997). Superoxide dismutase converts $\mathrm{O}_{2}$ into $\mathrm{H}_{2} \mathrm{O}_{2}$, glutathione peroxide converts $\mathrm{H}_{2} \mathrm{O}_{2}$ into harmless molecules. Secondary antioxidants prevent chain reactions of free radicals and stop tissue damage, for example, vitamin C, a-tocopherol, $\beta$-carotene, bilirubin, albumin, uric acid and mannitol. Tertiary antioxidants repair biomolecules damaged by free radicals and they include DNA repair enzymes, methionine and sulphoxide reductase (Heffiner and Repine, 1989). 
Some antioxidants act intracellularly; for example, glutathione peroxidase, superoxide dismutase, catalase, AA and metal binding proteins. Also, some antioxidants act extracellularly; for example, transferrin, uric acid and haptoglobin. In addition, some act both intra- and extracellularly (that is, on the cell membrane), for example, reduced glutathionine, urate, ascorbic acid (AA) and a-tocopherol (Halliwell, 1994).

Certain metalloprotein antioxidants act by sequestration of transition metals which are well established prooxidants. Transferrin, lactoferrin and ferritin act to reduce iron-induced oxidant stress (Maiorino et al., 1991). Nordihydroguaiaretic acid, a putative anti-cancer, is a potent in vitro scavenger of peroxynitrite $\left(\mathrm{ONOO}^{-}\right)$, singlet oxygen $\left(\mathrm{O}_{2}^{-}\right)$, hydroxyl radical $\left(\mathrm{OH}^{-}\right)$, superoxide $\left(\mathrm{O}_{2}^{-}\right)$, hypochlorous acid, and prevents in vivo ozone-induced tyrosine nitration in lungs (FlorianoSanches et al., 2006). Structural antioxidants such as androgens, glucocorticoids and progesterone act by altering their molecular structures (Ayo and Oladele, 1996).

\section{Antioxidant vitamins and their potential uses in} nitrate-induced disease processes.

There are associations between oxidative stress, antioxidant nutrients and chronic diseases (Clark, 1988). Nutraceutical therapy with nutrients, vitamins and physical exercise training have been proven to increase antioxidant capacity of the body (Karlsson, 1997). It was shown that alterations of gene expression and protein levels caused by experimentally induced oxidative stress and ROS related diseases can be normalised by dietary antioxidants (Knasmuller et al., 2008). Vitamins C, E and A have been well documented to have antioxidant effects among others. The use of these vitamins separately or in combination has been found to significantly affect physiological processes and alter the course of many diseases including, nitrate-induced oxidative stress.

\section{Vitamin C}

L-ascorbic acid (AA) is a water soluble vitamin and is widely distributed in fruits and vegetables (Singhal et al., 2001). AA is an effective antioxidant in many biological systems (Ayo et al., 2006; Ambali et al., 2007). It has an important metabolic role as a result of its reducing properties and function as an electron carrier. It can give up two electrons and in the process is converted to dehydro-AA. It takes part in redox and hydroxylation pathways, acting as a co-factor for cytochrome $\mathrm{P}_{450}$ dependent hydroxylases in some of these reactions (Whitehead and Keller, 2003). Both AA and dehydro-AA possess vitamin $C$ activity. AA can also form an ascorbate radical, giving another route to antioxidant activity by destroying free radicals derived from oxygen, including $\mathrm{OH}^{-}, \mathrm{O}_{2}^{-}$and superoxide (Williams, 1997; Whitehead and Keller, 2003). In this role, it may show a synergistic action with other protective enzymes including superoxide dismutase, glutathione peroxidase and catalase. This has been confirmed by Gecha and Fagan (1992), who showed that in vitro addition of AA decreased the rate of $\mathrm{H}_{2} \mathrm{O}_{2}$-induced proteolysis and also destruction of exogenously added superoxide dismutase. AA has been shown to be capable of decreasing haemolysis under in vitro conditions, apparently by strengthening the physical integrity of the erythrocytes (Awodi et al., 2005).

Ascorbic acid is also involved in the vitamin $\mathrm{E}$ antioxidant system, converting oxidised forms of a-tocopherol back to a-tocopherol (Whitehead and Keller, 2003). AA and vitamin $E$ have been shown to inhibit oxidative stress in cardiomyocytes, resulting in inhibition of all steps of apoptosis including condensation, membrane babbling, shrinkage and cytoplasmic condensation (Guan et al., 2004). Similarly, both vitamins affected nitrate toxicity in a dose-dependent manner (Yarube et al., 2009b). AA induces reduction in vascular sensitivity to catecholamines and enhancement of endotheliumdependent relaxation due to increased NO bioavailability (Singhal et al., 2001).

Ascorbic acid is one of several antioxidants shown to play key role in the prevention of many types of cancers. It maintains collagen, a protein necessary for the formation of skin, ligaments and bones. It also enhances the immune systems, helps heal wounds and mends fractures, aids in resisting some types of bacterial and viral infections (Whitehead and Keller, 2003), and participates in control of mood and brain functions (Balz, 2003). AA has been reported to protect sperm DNA from the damage induced by exogenous oxidative stress in vitro (Son et al., 2004). It was found to be protective against sodium nitrate-induced toxicity on sperm cells in rats (Yarube et al., 2009a).

Although AA is mostly considered to have an antioxidant effect, there are situations when it functions as a prooxidant. Podmore et al. (1998) reported paradoxical results in their in vivo study on DNA base oxidation. Daily supplementation of $500 \mathrm{mg}$ of AA caused decreased oxidation of guanine and increased oxidation of adenine. The oxidation of adenine suggests that AA acted as a pro-oxidant through formation of ascobyl radical. It is also known that this radical is quenched by conversion of glutathione to oxidised glutathione. High doses of AA may increase the concentration of ascorbyl radical, which if not quenched could result in an increased antioxidant burden (Jeffrey, 1998). Yarube et al. (2009b) reported decreased erythrocyte count and haemoglobin value by $A A$, and decreased erythrocyte count, packed cell volume and total serum proteins by vitamin $\mathrm{E}$ in sodium nitratetreated rats in chronic studies. The effects were worse when the two vitamins were administered together, suggesting a negative synergistic effect.

Similarly, AA serves as a pro-oxidant during its interaction with transition metals, especially iron. Ferrous $\left(\mathrm{Fe}^{2+}\right)$ iron reduces $\mathrm{H}_{2} \mathrm{O}_{2}$ to generate the $\mathrm{OH}$-radical and in the process becomes ferric $\left(\mathrm{Fe}^{3+}\right)$ iron. AA can convert $\mathrm{Fe}^{3+}$ back to $\mathrm{Fe}^{2+}$, itself being oxidised to dehydro-AA. Continued supply of AA can thus induce a series of cycles of AA-driven free radical generation from iron (Herbert et al., 1996). This system can be used in vitro to provide antioxidant stress. Although adverse effects may occur in vivo from the combination of elevated dietary concentrations of iron and $A A$, such effects may be largely restricted to the gastro-intestinal tract since inorganic iron is relatively poorly absorbed from the gut (Whitehead and Keller, 2003). Absorbed iron is usually bound to protein, for example, haemoglobin and ferritin, which may protect the ion from oxidative reactions. In humans, individuals with plasma AA concentrations at the upper limit of the normal range did not show any signs of oxidative damage to DNA when given supplemental iron (Proteggente et al., 2001). Indeed it has been demonstrated that AA can be tolerated at high doses without apparent side-effects (Balz, 2003). 


\section{Vitamin $E$}

Vitamin E (a-tocopherol) is a lipid-soluble membranelocalized antioxidant and present in circulating lipoprotein. It is the major lipid soluble chain-breaking antioxidant in plasma, red blood cells and other tissues (Javouhey-Donzel et al., 1993).

It is synthesised only by plants (Basu and Dikerson, 1996), and is therefore found primarily in plant products, the richest source being plant oils. The potent antioxidant properties of vitamin E were first demonstrated by Olcott and Matthil (1931). The effects of lipophilic antioxidant vitamin $\mathrm{E}$, vitamin $\mathrm{A}$ and coenzyme $\mathrm{Q}_{10}$ are catalysed and expanded in lipid-water interface by vitamin $C$ in the socalled Q-E-C cycles (Karlson, 1997). Vitamin E supplementation significantly lowers lipid peroxidation through increased glutathione levels (Sushil et al., 2000). Boadi (1991) found increased glutathione levels in the brain, liver, lungs and blood of rats treated with vitamin $\mathrm{E}$ $(120 \mathrm{mg} / \mathrm{kg}$ diet) for 30 days. Vitamin $\mathrm{E}$ may enhance the body's immune function and inhibit the conversion of nitrites to nitroso-amines in the stomach (Packer, 1991). It is required for normal functions of the immune system and control of aggregation of platelets. Vitamin $E$ is also involved in nucleic acid and protein metabolism, functions of the mitochondria and regulation of hormone production (Guthrie and Picciano, 1995). Other nonantioxidant functions include regulation of protein kinase C, modification of cell growth and proliferation and modification of gene transcription and expression (Azzi and Stocker, 2000).

Vitamin $E$ is involved in an extensive range of protective systems. It reversed the decrease in sperm counts of sodium nitrate-treated rats, apparently by antagonizing the loss of membrane integrity (Yarube et al., 2009a), thus serving as an effective antioxidant in antagonizing the free radical effect of nitrates (Hanafy and Soltan, 2004; Ocak, 2007; Suteu et al., 2007). It plays a role in prevention of atherosclerosis through inhibition of oxidation of LDL (Reaven, 1993); inhibits platelet adhesion, and is of benefit to diabetics (Jain et al., 2000) and patients with acquired immuno-deficiency syndrome

\section{REFERENCES}

Akinwande, A.I. and Adebule, A. O. A. (2003). Ascorbic acid and beta-carotene alleviate oxidative effect of

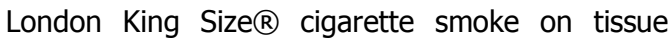
lipids. Nigerian Journal of Health and Biochemical Sciences. 2 (1): $12-15$.

Ambali, S., Akanbi, D., Igbokwe, N., Shittu, M., Kawu, M. and Ayo, J. (2007). Evaluation of subchronic chlorpyrifos poisoning on haematological and serum biochemical changes in mice and protective effect of vitamin C. The Journal of Toxicological Sciences. 32 (2): 111-120.

Antipina, V. D., Falunina, Z.P. and Moiseyev, Y. V. (1990). The Nitrate Problem and Methods of its Resolution. Moscow, $431 \mathrm{pp}$.

Antonov, B. I., Fedotova, V. I. and Sukhaya, N. A. (1989). Laboratory Investigation in Veterinary Medicine: Chemical and Toxicological Methods. Agroprdmizdat, Moscow, $320 \mathrm{pp}$.

Ariens, E. I., Simonis, A. M. and Offermeier, J. (1976). Introduction to General Toxicology, Academic Press, New York, 252 pp.
(AIDS) (Liang, 1996; Tang, 1997) as well as Parkinson's disease. Tissue-plasma levels of vitamins $E$ and vitamin $C$ and intracellular glutathione concentration decrease with age (Droge et al., 2006).

\section{Vitamin A}

The pro-vitamin A, $\beta$-carotene is a lipid soluble vitamin, and like other carotenoids play an important role in the protection of cells from oxidative damage due to their highly conjugated double systems (Mascio et al., 1991). Dietary intake of vitamins A, C and E may influence blood levels of catalase through their antioxidant effect on free radicals (Tabet et al., 2002). Vitamin A plays an important role in the protection of membrane from lipid peroxidation by free radicals (Mydlik et al., 2002). $\beta$ carotene reacts with peroxyl radical to form $\beta$-carotene radical. It is more efficient in conditions of low $\mathrm{O}_{2}$ tensions (Olsen and Kobayoski, 1992). It has been proposed that beta-carotene acts as an antioxidant by scavenging lipid peroxyl radicals, not by donating hydrogen atom, like vitamin $\mathrm{E}$ and $\mathrm{C}$, but by addition reaction to double bond to give resonance stabilised, carbon-centred conjugated radicals (Burton and Ingold, 1984). Beta-carotene has a protective role during aging as it reduces free radical damage to DNA (Williams, 1997). It has been used with other vitamins to cause down regulation of tumour necrosis factor (Son et al., 2004).

\section{Conclusion and recommendations}

Exposure to toxic effects of nitrates is inevitable, considering the increasing applications of nitrates in different sphere of life. It seems there is much more to be discovered about the extent of health hazards induced by nitrates to man and animals. The recent intensive research efforts into antioxidants and their potential uses in various disease processes need to be fully exploited in order to find practical solutions to the nitrate problem. Though such solutions appear to be in sight, some of the positive results must be further evaluated for variations in doses and possible combinations of different types of antioxidants from various sources.

Aruoma, O. I. (1994). Nutrition and health aspects of free radicals and antioxidants. Food and Chemicals Toxicology. 32 (7): $671-693$.

ATSDR (Agency for Toxic Substances and Disease Registry) (2001). Case Studies in Environmental Medicine: Nitrate/nitrite toxicity. Department of Health and Human Services, Wigington, P. S.(Ed), DTEM, U.S.A., 22 pp.

Awodi, S., Ayo, J.O., Nwude, C.I. and Dzenda, T.(2005). Effects of sodium nitrite and ascorbic acid on the erythrocyte osmotic fragility in Red Sokoto Goats. Proceedings of 10th Annual Conference, Annual Science Association of Nigeria (ASAN), University of Ado-Ekiti, Nigeria, $65-68$.

Ayo, J.O., Aliu, Y. O., Amber, E. I. and Rahamathullah, P. M. (1990). Effects of experimental ischaemiareperfusion injury on leucocytes-mediated haemolysis in dogs. In: Proceedings of Physiological Society of Nigeria, Jos, February, 1990, Pp. $41-42$.

Ayo, J. O., Minka, N. S. And Mamman, M. (2006). Excitability scores of goats administered ascorbic acid and transported during hot-dry conditions. Journal of Veterinary Science. 7(2):127-131. 
Ayo, J. O. and Oladele, S. B. (1996). Natural antioxdiants and their potential uses in prophylaxis and therapy of disease conditions. West African Journal of Pharmacology and Drug Research. 12: $69-76$.

Azenabor, A. A., Egbafona, N.O. and Nwanze, E.A. C. (1994). Relationship between superoxide dismutase activity and indirect haemglutination antibody titre in chlamydial infection. Nigerian Journal of Physiological Sciences. 10: 51 - 56.

Azhipa, Y. I., Reutov, V. P. and Kayushina, L. P. (1990). Ecological and medico-biological aspects of environmental pollution with nitrates and nitrites. Human Physiology. 16: $134-149$.

Azzi, A. and Stocker, A. (2000). Vitamin E: Nonantioxidant roles. Progress in_Lipid Research. 39: $231-255$.

Babsky, A. M. and Shostakovskaya, I. V. (1992). Effects of low concentration of sodium nitrite and nitrate on respiration and oxidative phosphorilation in the rat liver mitochondria. Ukrainian Biochemical Journal. 64: $71-74$.

Balz, F. (2003). Vitamin C intake. Nutritional Disease. 14: $1-18$.

Basu, T. K. and Dickerson, J. W. T. (1996). Vitamin E. In: Vitamins in Human Health and Disease. CAB International, Oxford, U. K., pp. $214-227$.

Bazan, N. G. (1992). Second messengers derrived from excitable membranes are involved in ischaemia and seizure-related brain damage. Pathologic Physiology and Experimental Therapy, 4:11-16.

Bensoltane, S., Messerer, L., Yuobi, M., Berrebbah, H., Djekoun, M. and Djebar, M. R., (2006). Effects of acute and sub-chronic ammonium nitrate exposure on rat liver and blood tissues. African Journal of Biotecnology. 5(9): 749-754.

Bkaily, G.and d'Orleans - Juste, V. (1999). Cytokineinduced free radicals and their role in myocardial dysfunctions. Cardiovascular Research. 42 (3): $576-577$.

Boadi, W.Y. (1991). Effects of dietary supplementation with vitamin $E$, riboflavin and selenium on central nervous system oxygen toxicity. Pharmacology and Toxicology. 68: $77-82$.

Boots, A.W., Harnen, G.G. and Bast, A. (2003). Oxidant metabolism in chronic obstructive pulmonary disease. European Respiratory Journal. 46: 14 27 (suppl.).

Bove, F. J., Fulcomer, M. C. and Klotz, J. B. (1992). Public Drinking Water Contamination and Birth Weight, Foetal Deaths and Birth Defects. A Cross sectional Study. Report on Phase IV-A. New Jersey Department of Health, Trenton, New Jersey, 207 pp.

Brender, J. D., Olive, J. M., Felkner, M., Suarez, L., Marckwardt, W. and Hendricks, K. A. (2004). Dietary nitrites and nitrates, nitosable drugs and neural tube defects. Epidemiology. 15: $330-336$.

Bruning-Fan, C. S. and Kaneene, J. B. (1993). The effects of nitrate, nitrite and $\mathrm{N}$-nitroso compounds on human health: A review. Veterinary and Human Toxicology. 35: $521-538$.

Bukowski, J., Somers, G.and Bryanton, J. (2001). Agricultural contamination of groundwater as a possible risk factor for growth restriction or prematurity. Journal of Occupational and Environmental Medicine. 43: 377 - 383.

Burton, G.W., and Ingold, K.U. (1984). Antioxidant actions of $\beta$-carotene. Science. 235: $569-573$.

Cedergren, M. I., Selbing, A. J., Lofman, O. and Kallen, B. A. (2002). Chlorination by-products and nitrates in drinking water and risk for congenital cardiac defects. Environmental Research. 89: 124-130.

Chabrier, P. E., Demerie-Pallardy, C. and Brawuat, P. (1962). Potential physiological and pathophysiological roles of nitric oxide in the brain. Pathological Physiological and Experimental Nitrate Poisoning of Bull Calves. Doctor of Philosophy Thesis. Ukrainian State Agriculture University, Kiev, $61 \mathrm{pp}$.

Chan, K., Truong, D., Shangari, N. and O'Brien, P. J. (2005). Drug-induced mitochondrial toxicity. Expert Opinion on Drug Metabolism and Toxicology. 1 (4): $655-669$.

Cheesman, K. N. (1993). Lipid peroxidation and cancer. In: DNA and Free Radicals, Halliwell, $\mathrm{B}$. and Aruoma, O. I. (eds). Ellis Horrowed, London, pp. $105-144$.

Chiveh, C. C., Andoh, T., Lai, A.R., Lai, E. and Rishna, G. (2000). Neuroprotective strategies in parkinson's disease: Protection against progressive nigral damage induced by free radicals. Neurotoxicology Research. $2(2-3): 293-310$.

Clark, J. M. (1988). Toxic action of oxygen. In: The Physiology and Medicine of Diving, Bennett, P. B. and Elliott, D.H. (eds), Meditsina Publsihing House, Moscow, pp. $190-246$.

Croen, L. A., Todoroff, K. and Shaw, G. W. (2001). Maternal exposure to nitrate from drinking water and diet and risk for neural tube defects. American Journal of Epidemiology. 153: 325 331.

Csovari, S., Angyal, T., Benko, K. and Strenger, J. (1992). Free radical reactions and cancer. Problems in Medical Chemistry, 38: 45 - 52.

Cutler, R. G. and Mattson, M. P. (2006). Adversities of aging. Aging Research Reviews. 5 (3): 221 - 238.

Davis, T.A., Gao, L., Yin, H., Morrow, J. D., and Porter, N. A. (2006). In vitro and in vivo lipid peroxidation of archidonate esters: The effect of fish oil omega-3 lipids on product and distribution. Journal of American Chemical Society. 128 (46): 14897 14909.

Del Maestro, R.F. (1980). An approach to free radicals in medicine and biology. Acta Physiologica Scandinavica. 492 (Suppl.): $135-168$.

Donovan, J.W. (1990): Nitrates, nitrites and other sources of methaemoglonaemia. In: Haddad, $B$. and Winchester, E. C. (Eds) Clinical management of poisoning and drug overdose. WB Sauders, Philadelphia, Pp. 1419 - 1431.

Droge, W., Kinscherf, R., Hildebrandt, W.and Schmitt, J. (2006). The deficit in low molecular weight thiols as a target for anti-aging therapy. Current Drug Targets. 7 (11): $1505-1512$.

Dudarev, V. P. (1987). Respiratory function of the blood. In: Seredenko, M. M. (Ed) Mechanisms of Development and Compensation of Haemic Hypoxia, Naukova Dumka, Kiev, 200 pp.

Dusheyko, A. A. (1989). Vitamin A - Metabolism and Function. Naukova Dumka, Kiev, 288 pp. 
Dursun, B., Dursun, E., Suleymanlar, G., Ozben, B., Capraz, I., Apaydin, A. and Ozben, T. (2008). Carotid artery intima-media thickness correlates with oxidative stress in chronic haemodialysis patients with accelerated atherosclerosis. Nephrology Dialysis Transplantation. 23 (5): 1697-1703.

Dykens, J. (2006). Oxidative stress and aging. Journal of Drugs. 4: $767-769$.

Fan, A. M. and Steinberg, V. E. (1996). Health implications of nitrate and nitrite in drinking water: An update on methaemoglobinaemia occurrence and reproductive and development toxicity. Regulatory Toxicology and Pharmacology. 23: $35-43$.

Floriano-Sanchez, E., Villanueva, C.,Medina-Campos,O. N., Rocha, D., Sanchez-Gonzalez, D. J., CardenasRodriguez, N. And Pedrazachauerri, J. (2006). Nordihydroguaiaretic acid is a potent in vitro scavenger of peroxynitrite, singlet oxygen, hydroxyl radical, superoxide anion and hypochlorous acid, and prevents in vivo ozone-induced nitration in lungs. Free Radical Research. 40(5): 523-533.

Galan, A. I., Palacios, E., Ruiz, F.F., Diez, A., Arji, M., Almor, M., Moneno, C., Celvo, J. I. Monoz, M. E., Delgado, M. A. and Jumenez, R. (2006). Exercise, oxidative stress and risk of cardiovascular disease in the elderly. Protective role of antioxidant functional food. Bio-factors. $27(1-4)$ : $167-183$.

Gecha, O.M. and Fagan, J. M.(1992). Protective effect of ascorbic acid on the breakdown of proteins exposed to hydrogen peroxide in chicken skeletal muscle. Journal of Nutrition. 12: 2089 - 2093.

Gnatyshak, A. I. (1988). General Clinical Oncology. Lvov State University Press, Lvov, 240 pp.

Gorbanov, N. V., Volgarev, A. P., Braylovskaya, I. V., Bykova, N. O. Avrova, N. F. and Kiselev, O.I. (1992). Activation of free radical reactions and alteration of the status of blood antioxidant defensive system following toxic experimental influenza infection. Bulletin of Experimental Biology and Medicine. 114 (7): $42-44$.

Gramov, L. A., Protyagina, V. A., Sereda, P. I. and Btobkova, L. S. (1993). Pharmacological analysis of free radical mechanism of intoxication memory disorders. Pathological Physiology and Experimental Therapy. 1: 8-10.

Griendling, K. K., Minieri, C. A., Ollerenshar, J. D. and Alexander, R.W. (1994). Angiotensin II stimulates $\mathrm{NADH}$ and NADPH oxidase activity in cultural vascular smooth muscle cells. Circulation, 74: 1141 1178.

Guan, Z., Lui, C. Y., Morkin, E. And Bahl, J. J. (2004). Oxidative stress and apoptosis in cardiomyocyte induced by high-dose alcohol. Journal of Cardiovascular Pharmacology. 44(6): 696-702.

Guichard, C., Pedruzzi, F., Fay, M., Ben-Mkaddem, S., Coant, N., Daniel, F. and Ogier-Dennis, F. (2006). The Nox Duox family of ROS-generating NADPH oxidases. Journal of Medical Sciences. 22 (11): 653 60.

Guthrie, H. A. and Picciano, M. F. (1995). Fat Soluble Vitamins in Human Nutrition, Mosby Company, New York, $420 \mathrm{pp}$.

Gutkin, V. S., Gorbatov, V. A. and Vostryyakov, A. P. (1986). Induced biochemiluminescence of macrophage during interaction with cell membranes of Mycobacteria bovis, In: Biochemiluminescence in
Agriculture, Zhuravlev, A. I. (ed.), Moscow, Veterinary Academy Press, Moscow. Pp. 35 - 37.

Hall, C. N., Robert, G., Keynes, R. G. and Garthwaite, J. (2009). Cytochrome P450 oxidoreductase participates in nitric oxide consumption by rat brain. Biochemical Journal, 419 (2): 411-418.

Halliwell, B. (1996). Mechanism involved in the generation of free radicals. Pathological Biology, 644 (1): $6-13$.

Hanafy, S. And Soltan, M. E. (2004). Effects of vitamin E pretreatment on subacute toxicity of mixture of $\mathrm{Co}$, $\mathrm{Pb}$ and $\mathrm{Hg}$ on nitrate-induced nephrotoxicity in rats. Environmental Toxicology and Pharmacology. 17 (3): $159-167$.

Hansen, P. R., Taxvig, C., Christiansen, C., Axelstad, M., Boberg, J., Kiersgaard, M. K., Nellemann, C. and Hass, U. (2009). Evaluation of Endocrine Disrupting Effects of Nitrate after In Utero Exposure in Rats and of Nitrate and Nitrite in the H295R and T-Screen Assay. Oxford Journals of Life Sciences \& Medicine, Toxicological Sciences. 108 (2): 437-444.

Heffiner,J, E. And Repine, J. E. (1989). Pulmonary striates of antioxidant defence. American Review of Respiratory Diseases. 140:531-543.

Herbert, V., Shaw, S. and Jayatilleke, E. (1996). Vitamin C-driven free radical generation from Iron. Journal of Nutrition. 126: $1213 S$ - 1220S.

Hryhorenko, L. M., Woskowska, Z. and Foxthrelkeld, J. A. E. T. (1995). Nitric oxide (NO) inhibits release of nitric oxide. The Journal of Pharmacology and Experimental Therapeutics, 211: 918 - 926.

Hultberg, M. and Hultberg, B. (2006). The effect of different antioxidants on glutathione turnover in human cell lines and their interaction with hydrogen peroxide. Chemical and Biological Interaction. 163 (3): $192-198$

Igbokwe, I.O., Esievo, K. A. N. and Saror, D. I. (1992). Freed radical pathology in trypanosomiasis - a new way ahead. In: Book of Abstracts of the Scientific Session. 29th Annual General Meeting of the Nigerian Veterinary Medical Association, 27th - 30th October. 1992, Pp. 43 - 44.

IPCS (International Programme on Chemical Safety) (1999). Nitrates and nitrites. Poisons, Information Monograph (Group Monograph) GO 16, Chemical. Ruse M. (Ed.), 35 pp.

Jacob, M. S. and Jandle, J. M. (1992). Effect of sulfhydryl inhibition on red blood cells. Glutathione in the regulation of hexose monophosphate pathway. Journal of Biological Chemistry, 14: $43-49$.

Jain, S., McVie, R. and Smith, T. (2000). Vitamin E supplementation restores glutathione and malondialdehyde to normal concentrations in erythrocytes of type I diabetic children. Diabetes Care. 23: 1389 - 1395.

Javouhey-Donzel, A., Guenot, L. And Maupoil, V. (1993). Rat vitamin $\mathrm{E}$ status and heart lipid peroxidation, effect of dietary oxylinoleic acid and morine n-3 Fatty Acids. Lipids. 28: 651-655.

Jeffrey, S. B. (1998): The prooxidant and antioxidant effects of vitamin C. Alternative Medicine Review. 3 (3): $170-173$.

Johannesson, T., Kristinsson, J. and Snaedal, J. (2003). Neutrodegenerative diseases, oxidative enzymes and copper. A Review of Experimental Research Leak, Nabladial. 89 (9): $659-671$. 
Karlson, J. (1997). Antioxidants and exercise. In: Principles of Radical formation, King, S. (ed), Saunders, Boston, Pp. $96-101$.

Karpovsky, V.I. (1994). Metabolic pathology following chronic nitrate poisoning of cattle and its prophylactic methods. Author's Comprehensive Summary of Doctor of Philosophy Thesis Ukrainian State Agricultural University, Kiev, 16 pp.

Kashko, N. F., Khokha, A. M., Antsulevich, S. N., Doroshkevich, N. A. and Voronov, P. P. (1993). The effect of ethanol and ethanol-induced lipid peroxidation on the steroidogenic activity of testes. Ukrainian Biochemical Journal. 65: 89-94.

Kasyanenko, I. V., Pinchuk, V. G. Mysasoyedov, D.V., Pivnyuk, V. M. and Osipova, L. A. (1992). Oncology, Naukova Dumka, Kiev, 264 pp.

Kerwin, J. F. Jr. (1995). Nitric oxide: A new paradigm for second messengers. Journal of Medical Chemistry. 38: 4343 - 4362 .

Khmelnitsky, G. A. (1990). Therapy of Animal Poisoning. Urozhay Publishing House. Kiev, 216 pp.

Kharitonov, S. A. and Barnes, P. J. (2003). Nitric oxide, nitrotyosine and nitric oxide modulators in asthma and chronic obstructive lung disease. Current Allergy and Asthma Research. 3 (2): 121 - 129.

Kislyakov, Y. Y. and Volzhskaya, A. M. (1993). Resistance of rats to acute hypoxia in nitrite methaemoglobinaemia. Pathological Physiology and Eperemental Therapy. 2: 35 - 37.

Knasmüller, S., Nersesyana, A., Mišíka, M., Gernera, C., Mikulitsa, W., Ehrlicha, V., Hoelzla, C., Szakmarya, A. and Wagnera, K. (2008). Use of conventional and omics based methods for health claims of dietary antioxidants: a critical overview. British Journal of Nutrition. 99: ES3-ES52.

Laven, R. A., Biggadike, H. J. and Allison, R. D. (2002). The effect of pasture nitrate concentration and concentrate intake after turn out on embryo growth and viability in the lactating dairy cow. Reproduction in Domestic Animals. 37: 111 - 115.

Lee, J. C., Son, Y. O., Choi, K. C. and Jang, Y. S. (2006). Hydrogen peroxide induces apoptosis of $B J A B$ cells due to formation of hydroxyl radicals via intracellular iron mediated fento chemistry in glucose oxidase mediated oxidant stress. Molecules and Cells. 22 (1): $21-29$.

Lewicki, J., Garwacki, S. and Wiechetek, M. (1994). Nitrate and nitrite kinetics after single intravenous dosage in sheep. Small Ruminant Research. 13: 141 $-146$.

Liang, B. (1996). Vitamins immunodulation in AIDS, Nutrition. 12: $1-7$.

Lu, C. Y., Lee, H. C., Fahn, H. J.and Wei, Y. H. (1999). Oxidative damage elicited by imbalance of free radical scavenging enzymes is associated with large scale MTDNA deletion in aging human skin. Mutation Research. 423 (1-2): $11-21$.

L'hirondel, J. and L'hirondel, J. L. (2000): Nitrate and man: toxic, harmless or beneficia? CABI Publishing, New York, 148 pp.

Madesh, M. and Balasubramanian, K. A. (1997). Activities of liver mitochondrial phospholipase $A_{2}$ by superoxide. Archives of Biochemistry and Biophysics. 346 (2): $187-192$.

Maiorino, M. Chu, F. F. And Ursino, F. (1991). Phospholipids hydroperoxide gluthione peroxidase in
$18 \mathrm{KDQ}$ selenoprotein expressed in human tumour cell lines. Journal of Biological Chemistry. 106: 77287732.

Manassaram, D. M., Backer, L. C. and Moll, D. M. (2006). A review of nitrates in drinking water: Maternal exposure and adverse reproductive and developmental outcomes. Environmental Health Perspective. 114 (3): 320 - 327.

Manja, V., Balsubrimanian, V. and Nahini, N. (2002). Oxidative stress and tumour markers in cervical cancer patients. Journal of Biochemistry and Molecular Biology and Biophysics. 6 (6): $387-389$.

Marklund, S. (1980). Distribution of CuZn superoxide dismutase in human tissues and extracellular fluids. Acta Physiologica Scandinavica. 492: $19-23$.

Mascio, P. D., Murphy, M. E. and Sies, H. (1991). Antioxidant defence system, the role of carotenoids, tocopherol and thiols. American Journal of Nutrition. 53: 1945-2005.

Mathys, M. J., Leonie, N., Johannes, A. M. And Robert, L. C. (1995). Purification of undegraded ceruloplasmin from outdated human plasma. Analytical Biochemistry. 146: 1- 6.

Metodiewa, D. and Koska, C. (2000). Reactive oxygen species and reactive nitrogen species: Relevance to cyto(neuro) toxic events and neurological disorders. An overview. Journal of Neurotoxicology Research. 1 (3): $197-233$.

Meyer, L. E., Machdo, L. B., Santiago, A. P., Da Silva, W. S., Defelice, F. G., Holub, O., Oliveira, M. F. and Galina, A. (2006). Mitochondria creatinin kinase activity prevents reactive oxygen species generation: Antioxidant role of mitochondrial kinase-dependent ADP recycling activity. Journal of Biology and Biochemistry. 107: 37-45.

Mircescu, G. (2008). Oxidative stress of chronic kidney disease. Acta Endocrinologica (Buc). 5 (4): 433 446.

Moncada, S., Palmer, R. M. J. and Higgs, E. A. (1991). Nitric oxide: Physiology, pathophysiology, and pharmacology. Pharmacological Reviews. 43: 109 142.

Morriel, P., Plannik, F.L., Zanella, M. T., Bertolami, M. C. and Abdalla, D.S. (2000). Lipid peroxidation and anti-oxidants in hyperlipidaemia and hypertension. Biology Research. 33 (2): $105-112$.

Mydlik, M., Derzscova, K., Reez, O., Spvlova, A., Boldizzsar, J., Lovasova, F. and Hribikova, M. (2002). Vitamin $\mathrm{E}$ as an antioxidant agent in COPD (Chronic Obstructive Pulmonary Disease) patients. International Journal of Artificial Organs. 25 (5): 373 $-378$.

NAS (National Academy of Science) (1977). Drinking Water and Health: Inorganic Solutes. National Academy of Science, Washington, D. C. Pp. 411 439.

Ocak, S., Gorur, S., Hakverdi, S.,Celik, S. and Erdogan, S., (2007). Protective effect of cafeic acid phenethyl esther, vitamin C, vitamin E and acetylcystein on vancomycin-induced nephrotoxicity in rats. Basic and Clinical Pharmacology and Toxicology. 100(5): 328333.

Oğur, R., Korkmaz A. and Hasde M. (2000). Effects of high nitrate intake in rats. Journal of Basic Clinical Physiology and Pharmacology. 11(1): 47-56. 
Oladele, S. B., Ayo, J. O. and Adaudi, A. O. (1997). The emergence of nitrate and nitrite poisoning in humans and domestic animals. West African Journal of Pharmacology and Drug Research. 13: $50-58$.

Olcot, H. S. and Matthill, H. A. (1931). The unsaponifiable lipids of lettuse. The_Journal of Biological Chemistry. III XC, 1: $59-64$.

Olsen, J. A. and Kabayoski, S. (1992): Antioxidants in health and disease. Overview. Experimental Biology and Medicine. 20: 13 -18.

Opaza, C., Ruiz, F. H. and Inestrosa, N. C. (2000). L amyloid - beta-peptide reduces copper II to copper I independent of its aggregation state. Biological Research. 33 (2): $125-131$.

Packer, L. (1991). Protective role of vitamin E in biological systems. American_Journal of Clinical Nutrition. 53: 1050S - 1055S.

Papov, B., Gadjeva, V., Valkanov, P., Papova, S.and Tolekova, A. (2003). Lipid peroxidation, superoxide dismutase and catalase activity in brain tumour. Archives of Physiology and Biochemistry. 111 (5): $455-459$.

Peranovich, T. M. S., Da Silva, A. M., Fries, D. M., Stern, A. and Monteiro, H.P. (1995). Nitric oxide stimulates tyrosine phosphorylation in murine fibroblasts in the absence and presence of epidermal growth factor. Biochemical Journal. 305: $613-619$.

Podmore, I.D., Griffiths, H. R. and Herbet, K. E., Mistry, P. and Lunes, J. (1998). Vitamin C exhibits prooxidant properties. Nature. 36: $392-559$.

Proteggente, A. R., England, T. G., Rice-Evans, C. A., and Halliwell, B. (2001). Iron supplementation and oxidative damage to DNA in healthy individuals with high plasma ascorbate. Biochemical and Biophysical Research Communications. 288: 24 251.

Prugar, J. and Prugaruva, A. (1990). Excessive Nitrogen in Vegetables. Agropromizdat, Moscow, $127 \mathrm{pp}$.

Punchard, N. A. and Kelly, F. J. (1997). Free Radicals: $A$ Practical Approach. DAC. Publishing, Houston, 200 pp.

Reaven, P. D. (1993). Effect of dietary antioxidant combinations in humans. Thrombosis. 13: $590-$ 600.

Riter, R. J. and Robinson, I. O. (1996). The Best Antioxidant in Melatonin. Drug Bontam Books, New York. 134 pp.

Rubenchik, B. L., Kostyukovsky, Y. L. and Melamed, D. B. (1983). Prophylactics of Contamination

of Food Products by Carcinogens, Zdorovya, Kiev, 160 pp.

Sax, V. A., Konorev, E. A., Grigoryantz, R.A. and Belenkov, K. N. (1992). Biochemistry of normal and ischaemic cardiac myocyte. Current research state. Cardiology. 32: 82 -91.

Seyfulla, R. D. and Borisova, J. G. (1990). Problems of antioxidant pharmacology. Pharmacology and Toxicology. 53 (6): $3-10$.

Sezer, E. D., Aksu, K., Caglayan, O., Keser, G., Karabulut, G. and Ercan, G. (2010). DNA damage and its relationship with other oxidative stress parameters in Behcet's disease. Rheumatology International
Clinical and Experimental Investigations. 10.1007/s00296-010-1605-0.

Shehata, S.A. (2005). Nitrate detoxification of drinking water by ascorbic acid in growing rabbits. World Rabbit Science. 13: 93 - 106.

Sidoryak, N. G. and Minyaylenko, T. D. (1991). Effect of prolonged administration of sodium nitrite on oxygen transport function and acid-base status of the blood._Pharmacology and Toxicology, 3: 88 92.

Sinclair, A.J., Barnett, A. H. and Lunec. J. (1990). Free radicals in anti-oxidant systems in health and disease. British Journal of Hospital Medicine. 43: $334-344$.

Singhal, S., Gupta, R. and Gogle, A. (2001). Comparison of antioxidant efficacy of vitamin $E$, vitamin $C$, vitamin $\mathrm{A}$ and fruits in coronary heart diseases. A controlled trial. Journal of the Association of Physicians, India. 49: 327 - 331.

Solodkov, A. P., Bozhko, A. P., Shebeko, V. I. and Rodionov, Y. Y. (1993). Autoregulation of coronary flow in the isolated rat heart following NOsynthase blockade. Bulletin of Experimental Biology and Medicine. 116: 240 - 244.

Son, E. W., Mo,S. J., Rhee, D. K. and Pyo, S. (2004). Vitamin C blocks TNF-alpha-induced NF-kappa B activation and ICAM-1 Expression in human neuroblastoma cells. Archives of Pharmacology Research. 27(10):1073-1079.

Sorokin, D. Y. (1991). Nitrification in mammalian tissue. Progress in Contemporary Biology. 111: 201 206.

Sung, N., Dayong, W., Dradley, S., Guohua, C. and Simin, N. (2000). Effect of long term dietary antioxidant supplementation on influenza virus infection. Journal of Gerontology and Biological Science. 55 (B): $496-503$.

Sushil, K. J., Robert, M. V. and Tiney, S. (2000). Vitamin $\mathrm{E}$ supplimentation restores glutathione and malonedialdehyde to normal concentrations in erythrocytes of type I diabetic children. Journal of Diabetic Children. Diabetes Care. 23(9): 1389 1394.

Suteu, R., Altuntas, I., Buyukvanli, B., Akturk, O., Koylu, $H$. and Delibas, N. (2007). The effects of diazozin on lipid peroxidation and antioxidant enzymes in rats erythrocytes: role of vitamins $\mathrm{E}$ and $\mathrm{C}$. Toxicology and Industrial Health. 23(1): 13 - 17.

Tabacova, S., Balabaeva, L. and Little, R. E. (1997). Maternal exposure to exogenous compounds and complications of pregnancy. Archives of Environmental Health. 52: $341-347$.

Tabet, N., Mentle, M. E. and Ornell, M. (2002). Exogenous antioxidant activities in belation to concurrent vitamins $A, C$ and $E$ Intake in demented. International Psychogeriatrics. 14(1): 7-15.

Taha, S. K., Ibrahim, Y., Ibrahim-Salah-Eldin, A. E. and Ibrahim, M. Y. (2004). Free radicals and antioxidants in stressed Albino rats. El-Minia Medical Bulletin. 15 (2): $318-329$.

Takano, K., Ogura, M., Yenoda, Y. and Nakamura, Y. (2005) Oxidative metabolites are involved in polyamine induced microglial cell death. Nueroscience. 134 (4): $1123-1131$. 
Tang, A. M.(1997). Association between serum vitamin A levels and HIV - 1 Disease Progression. AIDS. 11: $613-620$

Thomas, J. P., Oeiger, P. G., Mainorino, M., Ursini, F.and Girott, A. W. (1990). Enzymatic reduction of phospholipids and cholesterol hydroperoxides on lipoproteins. Biochimia and Biophysica Acta. 1245: $252-259$.

Tomoko, H., Yamada, Y., Hata, T., Mori, H., Yamomura, M., Tomonoga, M., Urada, Y., Goto, S. and Kondo, T. (1996). Relation of oxidative and glutathione synthesis to $\mathrm{CD}_{95}$ mediated apaptosis of adult $\mathrm{T}$ cell leukaemia cells. American Association of Immunology. 47: 22 - 28.

USGS (United States Geological Survey) (1996b). Nitrates in the Nation's Waters: Identifying Problems and Progress. FS - 218 - 96. Reston, V.A. National Water Quality Assessment Program. U. S. Geological Survey, 103 pp.

Valderranma, R., Corpas, F. J., Carreras, A., GomzRodrigues, M. V., Chaki, M., Pedrojas, J. R., Fermandez-Ocana, A., Del-Rio, L.A. and Barroso, J.B. (2006). The dehydrogenase-mediated recycling of $\mathrm{NADPH}$ is a key antioxidant system against salt-induced oxidative stress in a live plant. Plant Cell and Environment. 29 (7): 1449 1459.

Vannin, A. F., Manukhina, E. B., Lapshin, A. V. and Meerson, F. Z. (1993). Increased synthesis of nitric oxide in the aortic wall in experimental myocardial infarction. Bulletin of Experimental Biology and Medicine. 116 (8): $142-144$.

Vaziri, N. D., Wang, X. Q., Oveisi, F. and Rad, B. (2000). Induction of Oxidative Stress by Glutathione Depletion Causes Severe Hypertension in Normal Rats. Hypertension. 36:142-146.

Voskrensky, O. N., and Bobirev, V. N. (1992). Bioantioxidants are obligatory factor of nutrition. Problems in Medical Chemistry. 38: 21-26.
Whitehead, C. C. and Keller, T. (2003). An update on ascorbic acid in poultry. World's Poultry Science Journal. 59: $161-184$.

Williams, S. R., (1997). Recommended daily allowance. In: Nutrition and Diet Therapy, 8th edition, Mosby, St. Louis, Philadelphia, 243 pp.

Wogan, G. N., Generoso, W., Koller, L. D. and Smith, R.P. (1995). Nitrate and Nitrite in Drinking Water: National Academic Press, Washington, D.C., 73 pp.

Yarube, I.U. (2008). Study of the effects of antioxidant vitamins $C$ and $E$ on some haematological and male reproductive changes induced by chronic nitrate administration in rats. MSc thesis, Department of Human Physiology, Faculty of Medicine, Ahmadu Bello University, Zaria. 147 pp.

Yarube, I. U., Okasha, M. A., Ayo, J. O. and Olorunshola, K. V. (2009a). Antioxidant vitamins C and E alleviate the toxicity induced by chronic sodium nitrate administration on sperm count and serum testosterone level in Wistar rats. European Journal of Scientific Research. 25 (1): 35-41.

Yarube, I. U., Okasha, M. A. M. E. and Ayo, J. O. (2009b). Effects of vitamin $C$ and $E$ on some haematological parameters and serum proteins during chronic nitrate toxicity in Wistar rats. BEST Journal. 7 (1): 133-138.

Yoshikawa, T. (1993): Free radicals and their scavengers in Parkinson's disease. European Neurological Journal. 33 (1): $111-119$.

Zadorozhnaya, G. P. (1991). Methods of decreasing nitrate and nitrite value in livestock products. Ukrainian Research Institute of Science and Technical Information of the State Plan. Kiev, 44 pp.

Zandjani, F., Hogsaet, B., Andersen, A. and Langard, S. (1994). Incidence of canacer among nitrate fertilizer workers. International Archives of Occupational and Environmental Health. 66: 189 193. 